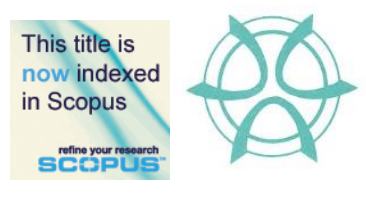

PLANNING MALAYSIA:

Journal of the Malaysian Institute of Planners

VOLUME 16 ISSUE 3 (2018) Page 261 - 273

\title{
ASSESSING A WALKABLE ENVIRONMENT IN JALAN TUANKU ABDUL RAHMAN, KUALA LUMPUR, MALAYSIA
}

\author{
Na'asah Nasrudin ${ }^{1}$, Muna Sarimin ${ }^{2} \&$ Norhayati Ibrahim ${ }^{3}$ \\ Faculty of Architecture, Planning and Surveying \\ UNIVERSITI TEKNOLOGI MARA, MALAYSIA
}

\begin{abstract}
There is currently a wide discussion on promoting a walkable environment and improving walkability especially in city centre. Walking in the city is meant to solve numerous problems ranging from the city vibrancy, traffic congestion, environmental injustice, social isolation to the human health issues related to obesity crisis. This paper aims to examine the walkable environment of Jalan Tuanku Abdul Rahman as one of the busiest pedestrian urban places in the city centre of Kuala Lumpur, the capital city of Malaysia. It investigates the pedestrians' perception on their walking experience based on the walkable environment elements i.e. comfort, safety and levels of enjoyment. A participant observation and questionnaire survey technique were employed whereby the former involved with the researchers general physical evaluation of the site and the latter engaged a random sample of 120 pedestrians of Jalan Tuanku Abdul Rahman for a paper-based on street questionnaire survey. The findings suggested that the majority of the respondents were satisfied with the existing conditions of comfort and safety and hence, regarded Jalan Tuanku Abdul Rahman as a walkable area. However, their level of enjoyment was generally minimal suggesting that there are rooms for further improvement in the pedestrian area to create a better and more conducive walkable environment.
\end{abstract}

Keywords: walkable, enjoyable walkway, pedestrian walkway 
Na'asah Nasrudin, Muna Sarimin \& Norhayati Ibrahim

Assessing a Walkable Environment in Jalan Tuanku Abdul Rahman, Kuala Lumpur, Malaysia

\section{INTRODUCTION}

Recent studies have confirmed that car culture is on the decline in the city centre and that increasing attention is being paid to walkable spaces and walkability to make cities more vibrant and attractive, sustainable, healthier and safer. Walking is the elementary means of people moving around, integrating and living the urban space and accomplishing a salutary physical activity. Many benefits have also been associated with walking, ranging from reducing traffic congestion and pollution to controlling health crisis related to obesity. Walking can also be regarded as an essential factor in the creation of liveable communities. Walkability is usually linked to the quality of the built environment and connected by the quality of the pedestrian environment. A walkable environment is often attractive because it is lively and sociable, pleasant, clean and full of interesting people. Creating walkable environment for pedestrians can improve urban conditions. It is also seen such environment will be able to promote environmental preservation, maintaining social equity components of sustainable urban form as well as providing a more sustainable transportation options. These save energy and provide opportunities for those who cannot use cars because of age, income and disability. With such associated benefits, critical questions are normally posed to researchers, particularly the urban planners: how best to promote walking and to what extent our built environment is able to encourage people to walk. This paper, therefore, aims to examine the walkable environment of Jalan Tuanku Abdul Rahman as one of the busiest pedestrian urban places in the city centre of Kuala Lumpur, the capital city of Malaysia. This paper is structured into six sections. The subsequent section is the research background comprising the literature review of the study. Section three and four explains about the study area and research methodology respectively. They are then followed by the results and discussion section and finally, a section on conclusion and implications of the results.

\section{RESEARCH BACKGROUND}

A walkable environment is often multidimensional in terms of means and these dimensions are normally measureable. According to Rahaman, Lourenco and Viegas (2012), a pedestrian space should have some essential elements in order to meet the needs and comfort of people. Besides, it needs to be managed efficiently and effectively to promote a conducive environment, sustainable and eco-friendly to be used by multiple ages of users with a different ability. Meanwhile, Shamsuddin, Hassan and Bilyamin (2012), and Llewelyn-Davies (2000) argued that the street design must be a sign of its street activities whereby for a the specific commercial street, the design of the street must be able to reflect the on-going the commercial activity.

Much has been written on the elements necessary for a supportive pedestrian environment. Sarkar and Janardhan (1997) have used similar criteria 
PLANNING MALAYSIA

Journal of the Malaysia Institute of Planners (2018)

for evaluating how well streets can serve pedestrians. Both assigned grades to streets based on how successful they were in the following categories: safety and security, continuity of the pedestrian network, system coherence, convenience and comfort, and attractiveness. The enhancement of a liveable street will also able to promote a safer urban environment. From the environmental point of view, walking is a "green" mode of transport, as it has a low environmental impact, without air and noise pollution. The presence of a walkable environment and transit systems will create a smart alternative to private car usage, thus reducing traffic congestion, noise, and emissions.

One of the thrusts of development in a rapid city is to utilise resources in an efficient manner in order to achieve sustainable development. It is translated in the principles of sustainable urban design by creating a walkable environment to encourage and facilitate communities in the city to walk. To materialise the idea of a sustainable city, a network of safe and comfortable pedestrian area through physical design in cities should be planned, implemented and monitored (Shamsuddin et al., 2012).

Many factors have been considered to be limitations or constraints to walking in an urban area (Handy, Xinyu, \& Mokhtarian, 2005). The limitation factors include stressors, like crowding, noise, traffic congestion, community violence and crime and physical features that reduce the sense of place. The safety factor (as in fear of crime) has been frequently cited as the highest constraint to walking by the more vulnerable groups and the people who rely more on walking (Evans 2009). Meanwhile, travel behaviour theories have been useful in understanding the factors that influence people to walk and what do people value most in any of their walking experience. Travel behaviour is influenced by situational and personal factors (Bouscasse, Joly, \& Bonne, 2018). Sociopsychological factors like attitudes towards the environment and certain modes of transport or the importance of moral obligation and environmental beliefs are the main influencing variables for daily travel. People with high environmental concern have a better perception of "green" mode transport like cycling and walking.

\section{THE STUDY AREA}

With a population of over 1.5 million, Kuala Lumpur is the largest city in Malaysia and growing rapidly. Being an international commercial and financial centre, the city has put in a tremendous and concerted effort to enhance its attractiveness and this include improving selected street in Kuala Lumpur for pedestrians. The Kuala Lumpur Structure Plan 2020 has identified Jalan Tuanku Abdul Rahman (TAR) as one of the major spines and part of the City Centre Commercial (CCC) Zone. It is designated as such to promote broad range of commercial activities to be conducted within walking distance and therefore, providing the highest potential in supporting Kuala Lumpur's economic growth. 
Na'asah Nasrudin, Muna Sarimin \& Norhayati Ibrahim

Assessing a Walkable Environment in Jalan Tuanku Abdul Rahman, Kuala Lumpur, Malaysia

This promotes walking in the area to be safer, faster and more efficient, thereby helping to strengthen the economic viability of the city in terms of commercial activity, retailing and tourism. At present, there is a wide range of facilities available along the $1.9 \mathrm{~km}$ length of the road including public transport system, shopping complexes, education and business centres offering a broad range of pedestrian activities including shopping, leisure, working and commuting transit. On the shoulders of this road are pre-war buildings, retail shops and modern shopping complexes (Sogo and Maju Junction). On Every Saturday between 5pm to $10 \mathrm{pm}$, part of the road will be closed for vehicles to make room for the night market that offers a variety of domestic items, clothing and food at attractive prices. This Jalan TAR night market is now seen as one of the KL icon and valued as a tourist attraction in Malaysia. Figure 1 shows the location of the study area and the divisional zones for observation survey (explained in section 4).

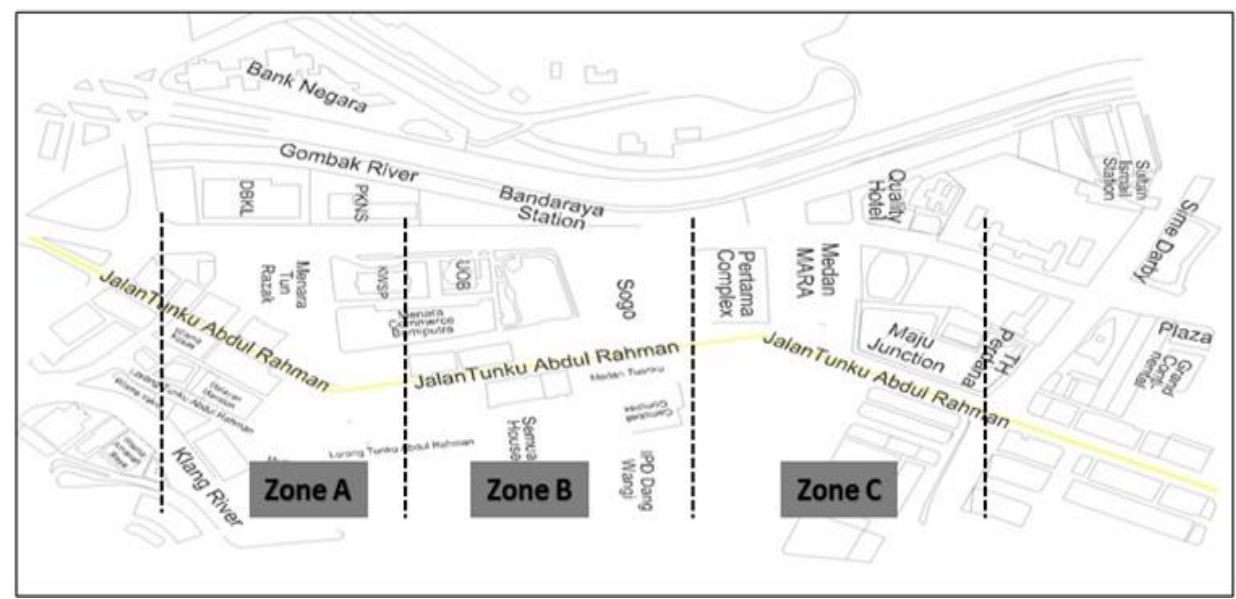

Figure 1: Map of the study area

\section{THE METHODOLOGY}

The assessment of the walking environment has been conducted by employing participant observation (physical survey) and on-street questionnaire survey techniques. Site evaluation was carried out at different stations and time (weekday and weekend, peak and off peak) to observe the physical aspects of Jalan TAR. The observation was done according to these three parameters i.e., comfort and image, safety, uses and activities. A checklist, zonal mapping and series of photographs have been used to record information gathered. Two separate groups of researchers (two members for each group) have been assigned at three different locations (Zone A, B and C as shown in Figure 1) to conduct the observation survey to ensure validity, conformity and more coordinated results. The results from the observation survey was also used as a guidance to develop the questionnaire for the second stage of data collection. 
PLANNING MALAYSIA

Journal of the Malaysia Institute of Planners (2018)

For on-street questionnaire survey, a total of 120 respondents were selected randomly among the pedestrians around Jalan TAR sidewalk. The survey was carried out during afternoon peak hour on both working weekdays and weekends. The respondents were provided with a paper-based survey form with several sub-item tests to gauge their walking experience based on walkable and enjoyable elements. Respondents were also asked to assess the pedestrian facilities, security level, and accessibility linking to other various mode of transportation. They were also asked to provide their future recommendations on strategies to further encourage walking, making walking to be more attractive, efficient and enjoyable activity and more importantly, create a more conducive and walkable environment.

\section{RESULTS AND DISCUSSION}

\section{Observation Analysis on Jalan TAR Walkable Environment}

The pedestrian walkway and quality of sidewalk network is seen as comfortable enough to link users to and from adjacent places. The observation results indicates that the size of the pedestrian walkway was acceptable and at a satisfactory level to accommodate high number of pedestrian with minimal clashes during the nonpeak hours. However, during peak hours, when the number of pedestrian increases and the situation gets busier, there was a slight obstruction in the walkway due to the existence of street vendors which often impedes pedestrian movements and creating conflicts between pedestrian space and walkways with vehicular movements. This also hampered the optimization of a walkable public space, which limits the size of sidewalk at both sides leading to other problems associated with the pedestrian traffic.

The result from the observation also shows that the street was generally safe with the presence of auxiliary police and security guards. At some points however, the pedestrians were at risk of petty crimes such as snatch theft as the walkway was located too close to the main road. However, at certain areas, improvements have been made to the pedestrian walkway like the provision of the guardrail as a safety element and crime prevention from vehicle and snatcher. In term of cleanliness, it could be considered as at moderate level whereby some areas were littered. Some areas of the pedestrian walkway had been vandalised and were not well maintained, and these could cause danger to the pedestrians.

In term of uses and activities, part of the pedestrian area functions as place for the exchange of goods or place to do business. The street vendors used the pedestrian space as a place to display their products and this has attracted the pedestrians to stop by, thus disrupting the pedestrian traffic flow. The pedestrian walkway, besides being a public space, has traditionally served as a place to do conduct commercial transactions. Besides the use of the walkway as a place for trading, numerous other forms of economic-based informal street activities, such 
Na'asah Nasrudin, Muna Sarimin \& Norhayati Ibrahim

Assessing a Walkable Environment in Jalan Tuanku Abdul Rahman, Kuala Lumpur, Malaysia

as petty traders, push carts, street vendors and street musicians have occupied most part of the pedestrian space. It was also observed that the area was highly used by people with disabilities. A number of people walking with walking sticks and crutches, and group of people who were visually impaired could be seen, benefitting the traffic free environment.

The road networks mainly serve the outer section of the area. A network of narrow alleys, approximately 1.5 to 3 meters wide, serves most of the area of Jalan TAR. However, on some days especially weekends and peak hour during weekdays, conflicts between pedestrians and vehicles could be traced at some parts of the pedestrian area. It was also observed that there was no sheltered walkway provided along the pedestrian walkway. The perennial heat and rainy conditions of Kuala Lumpur give rise to high humidity which makes strolling along the streets of Jalan TAR a "hot and sticky" affair. However, even without visible design landscape in the street, the observation concludes that users would still continue walking despite the weather affecting them. This clearly illustrates that the pedestrian walkway was functioning well and its physical characteristics act as a mode of movement for users (refer to the first photo in Table 1).

Table 1: Summary of the observation survey

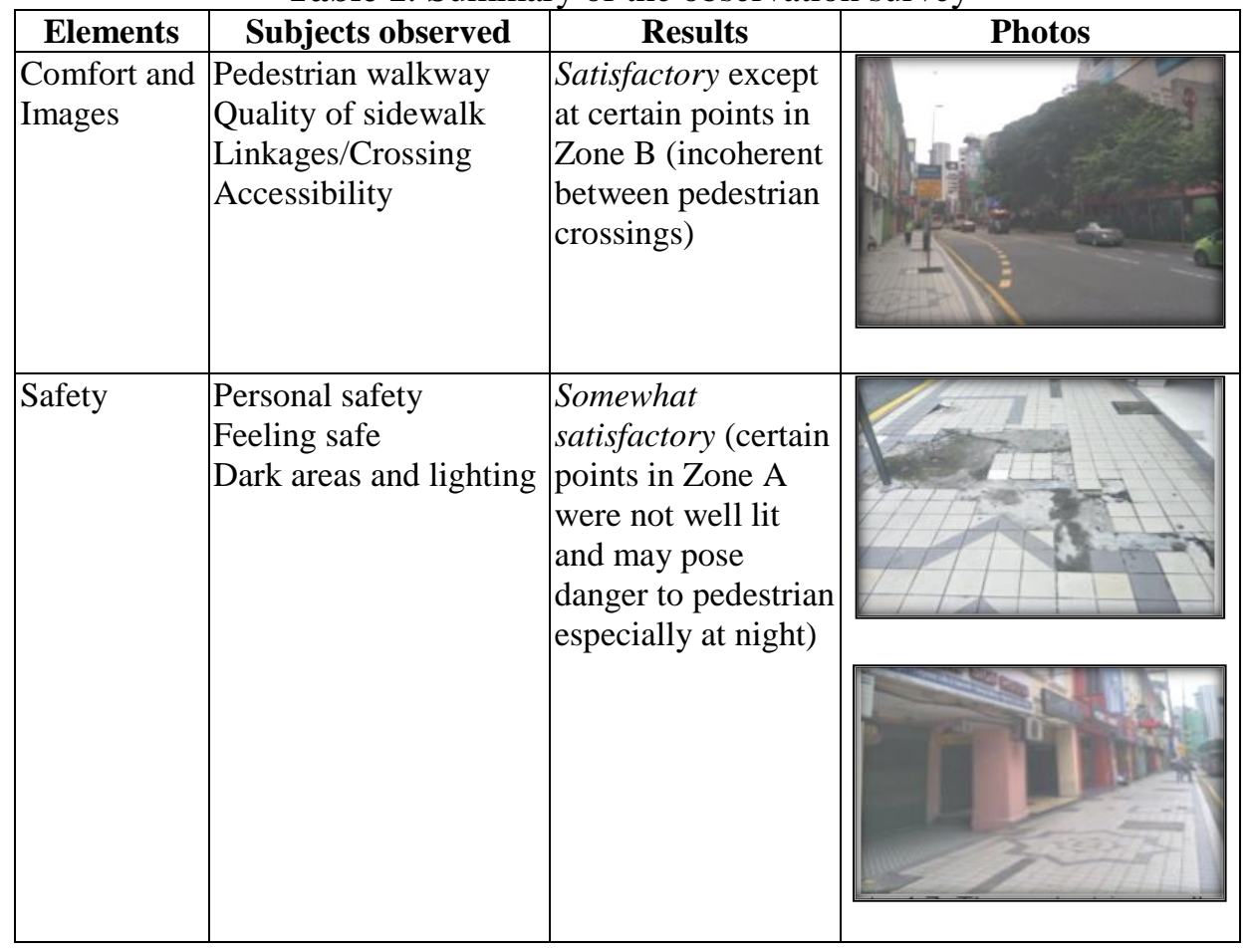




\begin{tabular}{|l|l|l||l|l|}
\hline $\begin{array}{l}\text { Uses and } \\
\text { Activities }\end{array}$ & $\begin{array}{l}\text { Conflict of activities } \\
\text { Size of walkway }\end{array}$ & $\begin{array}{l}\text { Somewhat } \\
\text { satisfactory (there } \\
\text { was a clash between } \\
\text { different types of } \\
\text { uses at all zones } \\
\text { observed) }\end{array}$ \\
\hline
\end{tabular}

\section{Pedestrians' Perception on Jalan TAR Walkable Environment}

\section{Elements of Comfort}

Comfortable walking has been associated with higher travel rates (Alfonzo, 2005). Slater (1985) described comfort as "the physiological, emotional and physical harmony between the human body and the environment." Facilitators of physical facilities (line, seating and adequate protection from the weather) can minimize the required effort. Sarkar and Janardhan (1997) defined comfort of walking as "to do activities and thus make the walk fun".

Because comfort can create good and positive images in place (Lynch, 1960), providing comfort in the interior of the city is important for a tourist experience. It is said that the quality of the running environment affects people on foot (Southworth, 2005). Parks and Schofer (2006) mentioned that network design helps determine the ability of pedestrians to reach their destinations, which corresponds to the state of the built environment. The importance of connectivity has been discussed by Brown, Werner, Amburgey and Szalay (2007). They mentioned that walkable environment must be able to provide comfort for pedestrians, can be improved with stronger linkages and promote a better quality pedestrian network within the district as a whole.

A pleasant and exciting walking experience has a positive impact on the perception of urban dwellers. In measuring comfort, several assessments were used to examine visitors' satisfaction over physical elements such as how well pedestrian elements can influence emotional comforts and how the visitors react to the qualities they experienced while walking.

Table 2: Pedestrians perception on Jalan TAR comfort elements

\begin{tabular}{|c|c|c|c|c|c|c|c|c|}
\hline \multicolumn{2}{|r|}{ Elements } & & $\begin{array}{c}(1) \\
\text { Strongly } \\
\text { Disagree }\end{array}$ & $\begin{array}{c}(2) \\
\text { Disagree }\end{array}$ & $\begin{array}{c}(3) \\
\text { Average }\end{array}$ & $\begin{array}{c}(4) \\
\text { Agree }\end{array}$ & $\begin{array}{c}(5) \\
\text { Strongly } \\
\text { Agree }\end{array}$ & Total \\
\hline & \multicolumn{8}{|l|}{ Comfort } \\
\hline 1 & $\begin{array}{l}\text { Condition } \\
\text { of sidewalk } \\
\text { are safe for } \\
\text { walking }\end{array}$ & $\begin{array}{c}\text { Total } \\
(\%) \\
\text { Mean 3.28 }\end{array}$ & $\begin{array}{c}3 \\
(2.5)\end{array}$ & $\begin{array}{c}19 \\
(15.8)\end{array}$ & $\begin{array}{c}45 \\
(37.5)\end{array}$ & $\begin{array}{c}47 \\
(39.2)\end{array}$ & $\begin{array}{c}6 \\
(5)\end{array}$ & $\begin{array}{c}120 \\
(100)\end{array}$ \\
\hline 2 & $\begin{array}{l}\text { Pedestrian } \\
\text { walkway is } \\
\text { well } \\
\text { maintained }\end{array}$ & $\begin{array}{c}\text { Total } \\
(\%) \\
\text { Mean 3.11 }\end{array}$ & $\begin{array}{l}6 \\
(5)\end{array}$ & $\begin{array}{c}15 \\
(12.5)\end{array}$ & $\begin{array}{c}61 \\
(50.8)\end{array}$ & $\begin{array}{c}36 \\
(30)\end{array}$ & $\begin{array}{c}2 \\
(1.7)\end{array}$ & $\begin{array}{c}120 \\
(100)\end{array}$ \\
\hline
\end{tabular}


Na'asah Nasrudin, Muna Sarimin \& Norhayati Ibrahim

Assessing a Walkable Environment in Jalan Tuanku Abdul Rahman, Kuala Lumpur, Malaysia

\begin{tabular}{|c|c|c|c|c|c|c|c|c|}
\hline 3 & $\begin{array}{l}\text { Enough } \\
\text { room for } \\
\text { walking }\end{array}$ & $\begin{array}{c}\text { Total } \\
(\%) \\
\text { Mean 3.49 } \\
\end{array}$ & $\begin{array}{c}0 \\
(0)\end{array}$ & $\begin{array}{c}14 \\
(11.7)\end{array}$ & $\begin{array}{c}43 \\
(35.8)\end{array}$ & $\begin{array}{c}53 \\
(44.20)\end{array}$ & $\begin{array}{c}10 \\
(8.3)\end{array}$ & $\begin{array}{c}120 \\
(100)\end{array}$ \\
\hline 4 & $\begin{array}{l}\text { Walkway } \\
\text { dirty and } \\
\text { littering } \\
\text { everywhere }\end{array}$ & $\begin{array}{c}\text { Total } \\
(\%) \\
\text { Mean 3.04 }\end{array}$ & $\begin{array}{c}5 \\
(4.2)\end{array}$ & $\begin{array}{c}8 \\
(6.7)\end{array}$ & $\begin{array}{c}45 \\
(37.5)\end{array}$ & $\begin{array}{c}51 \\
(42.5)\end{array}$ & $\begin{array}{c}11 \\
(9.2)\end{array}$ & $\begin{array}{c}120 \\
(100)\end{array}$ \\
\hline 5 & $\begin{array}{l}\text { Vehicle } \\
\text { exhaust } \\
\text { odour } \\
\text { on this } \\
\text { street } \\
\end{array}$ & $\begin{array}{c}\text { Total } \\
(\%) \\
\text { Mean 3.73 }\end{array}$ & $\begin{array}{c}2 \\
(1.7)\end{array}$ & $\begin{array}{c}11 \\
(9.2)\end{array}$ & $\begin{array}{c}25 \\
(20.8)\end{array}$ & $\begin{array}{c}62 \\
(51.7)\end{array}$ & $\begin{array}{c}20 \\
(16.7)\end{array}$ & $\begin{array}{c}120 \\
(100)\end{array}$ \\
\hline 6 & $\begin{array}{l}\text { Bad odour } \\
\text { on this } \\
\text { street }\end{array}$ & $\begin{array}{c}\text { Total } \\
(\%) \\
\text { Mean 3.34 } \\
\end{array}$ & $\begin{array}{c}0 \\
(0)\end{array}$ & $\begin{array}{c}23 \\
(19.2)\end{array}$ & $\begin{array}{c}41 \\
(34.2)\end{array}$ & $\begin{array}{c}48 \\
(40)\end{array}$ & $\begin{array}{c}8 \\
(6.7)\end{array}$ & $\begin{array}{c}120 \\
(100)\end{array}$ \\
\hline 7 & $\begin{array}{l}\text { Sidewalk } \\
\text { leads to and } \\
\text { from } \\
\text { adjacent } \\
\text { areas }\end{array}$ & $\begin{array}{c}\text { Total } \\
(\%) \\
\text { Mean 3.63 }\end{array}$ & $\begin{array}{c}0 \\
(0)\end{array}$ & $\begin{array}{c}11 \\
(9.1)\end{array}$ & $\begin{array}{c}30 \\
(25)\end{array}$ & $\begin{array}{c}71 \\
(59.1)\end{array}$ & $\begin{array}{c}8 \\
(6.6)\end{array}$ & $\begin{array}{c}120 \\
(100)\end{array}$ \\
\hline 8 & $\begin{array}{l}\text { Vehicles } \\
\text { dominates } \\
\text { pedestrians }\end{array}$ & $\begin{array}{c}\text { Total } \\
(\%) \\
\text { Mean 3,62 } \\
\end{array}$ & $\begin{array}{c}0 \\
(0)\end{array}$ & $\begin{array}{c}13 \\
(10.8)\end{array}$ & $\begin{array}{c}38 \\
(31.6)\end{array}$ & $\begin{array}{c}51 \\
(42.5)\end{array}$ & $\begin{array}{c}18 \\
(15)\end{array}$ & $\begin{array}{c}120 \\
(100)\end{array}$ \\
\hline 9 & $\begin{array}{l}\text { Accessible } \\
\text { by various } \\
\text { mode of } \\
\text { transportati } \\
\text { on }\end{array}$ & $\begin{array}{c}\text { Total } \\
(\%) \\
\text { Mean 3.73 }\end{array}$ & $\begin{array}{c}0 \\
(0)\end{array}$ & $\begin{array}{c}6 \\
(5)\end{array}$ & $\begin{array}{c}36 \\
(30)\end{array}$ & $\begin{array}{c}62 \\
(51.7)\end{array}$ & $\begin{array}{c}16 \\
(13.3)\end{array}$ & $\begin{array}{c}120 \\
(100)\end{array}$ \\
\hline 10 & $\begin{array}{l}\text { Space } \\
\text { function for } \\
\text { people with } \\
\text { special } \\
\text { needs }\end{array}$ & $\begin{array}{c}\text { Total } \\
(\%) \\
\text { Mean3.17 }\end{array}$ & $\begin{array}{c}0 \\
(0)\end{array}$ & $\begin{array}{c}39 \\
(32.5)\end{array}$ & $\begin{array}{c}34 \\
(28.3)\end{array}$ & $\begin{array}{c}35 \\
(29.2)\end{array}$ & $\begin{array}{c}12 \\
(10)\end{array}$ & $\begin{array}{c}120 \\
(100)\end{array}$ \\
\hline 11 & $\begin{array}{l}\text { There are } \\
\text { enough } \\
\text { places to sit }\end{array}$ & $\begin{array}{c}\text { Total } \\
(\%) \\
\text { Mean2.57 } \\
\end{array}$ & $\begin{array}{c}0 \\
(0)\end{array}$ & $\begin{array}{c}73 \\
(60.8)\end{array}$ & $\begin{array}{c}32 \\
(26.6)\end{array}$ & $\begin{array}{c}9 \\
(7.5)\end{array}$ & $\begin{array}{c}6 \\
(5)\end{array}$ & $\begin{array}{c}120 \\
(100)\end{array}$ \\
\hline
\end{tabular}

Table 2 shows the respondents' perceptions of comfort element at Jalan TAR. Respondents generally rated most of the comfort elements as satisfactory. It includes the criteria of the pedestrian walkway condition, acceptable walkway width and the connectivity of the pedestrian walkway to the adjacent areas. Respondents also highly agreed that the pedestrian walkway was accessible by various modes of transportation (highest mean score at 3.73). However, the quality of pedestrian walkway maintenance was rated as average. Hence, the respondents agreed that the walkway is not clean and have unpleasant odours. Respondents also gave negative feedbacks on the provision of space for people with special needs and also the lack of a place to sit (mean score lowest at 2.57).

Based on the previous research, Rahaman et al. (2012) mentioned that the current city centre of Kuala Lumpur is not a pedestrian-friendly city due to its lack of pedestrian linkages and existence of major deficiencies such as poor maintenance, inefficient design, and poor accessibility. Visitors often find 
PLANNING MALAYSIA

Journal of the Malaysia Institute of Planners (2018)

deficiencies in the pedestrian sidewalk facilities that are physically challenging to the disabled and the elderly. Unlicensed vendors and hawkers use the pedestrian sidewalk for their business purposes and some building owners prohibiting public access across their properties have worsen this scenario (Rahaman et al., 2012). Reduction in total sidewalk width due to the vendor's existence often impedes pedestrian movements. A city centre is not a pedestrianfriendly city if it lacked of pedestrian linkages and existence of major deficiencies such as poor maintenance, inefficient design and poor accessibility (Tarudin, Rashid, Kordi, Azmi, \& Aziz, 2016).

\section{Elements of Safety and Security}

Safety and security element is one of the determinants of a good and effective walkable environment. A safe pedestrian environment allows the pedestrians to walk comfortably and reduces the sense of fear of accident or crime (Zakaria \& Ujang, 2015). The intensity of pedestrian is required to increase safety because the streets will be more alive and lively (Jacobs, 1969). The components of the pedestrian safety are also associated with motorist behaviour, and crossing exposure and security. As noted by Newman (2008), the urban designs are important to avoid the formation of hidden and obscured niches in order to reduce crime on the streets. Hidden and obscured niches can be criminal hideout and expose the user to crime especially at a place with low intensity of pedestrians.

Table 3: Pedestrians' perception on Jalan TAR safety and security

\begin{tabular}{|c|c|c|c|c|c|c|c|c|}
\hline & Elements & & $\begin{array}{c}\text { (1) } \\
\text { Strongly } \\
\text { Disagree }\end{array}$ & $\begin{array}{c}(2) \\
\text { Disagree }\end{array}$ & $\begin{array}{c}\text { (3) } \\
\text { Average }\end{array}$ & $\begin{array}{c}(4) \\
\text { Agree }\end{array}$ & $\begin{array}{c}(5) \\
\text { Strongly } \\
\text { Agree }\end{array}$ & Total \\
\hline & \multicolumn{8}{|c|}{ Safety and Security } \\
\hline 1 & $\begin{array}{l}\text { Feeling safe } \\
\text { walking } \\
\text { along the } \\
\text { pedestrian }\end{array}$ & $\begin{array}{l}\text { Total } \\
(\%) \\
\text { Mean }\end{array}$ & $\begin{array}{c}0 \\
(0) \\
3.26\end{array}$ & $\begin{array}{c}17 \\
(14.2)\end{array}$ & $\begin{array}{c}60 \\
(50)\end{array}$ & $\begin{array}{c}38 \\
(31.7)\end{array}$ & $\begin{array}{c}5 \\
(4.2)\end{array}$ & $\begin{array}{c}120 \\
(100)\end{array}$ \\
\hline 2 & $\begin{array}{l}\text { Crossing the } \\
\text { street }\end{array}$ & $\begin{array}{c}\text { Total } \\
(\%) \\
\text { Mean }\end{array}$ & $\begin{array}{c}9 \\
(7.5) \\
2.76\end{array}$ & $\begin{array}{c}36 \\
(30)\end{array}$ & $\begin{array}{c}50 \\
(41.7)\end{array}$ & $\begin{array}{c}25 \\
(20.8)\end{array}$ & $\begin{array}{c}0 \\
(0)\end{array}$ & $\begin{array}{c}120 \\
(100)\end{array}$ \\
\hline 3 & $\begin{array}{l}\text { Distance of } \\
\text { road to the } \\
\text { sidewalk }\end{array}$ & $\begin{array}{c}\text { Total } \\
(\%) \\
\text { Mean }\end{array}$ & \begin{tabular}{l}
\multicolumn{1}{c}{13} \\
$(10.8)$ \\
2.47 \\
\end{tabular} & $\begin{array}{c}57 \\
(47.5)\end{array}$ & $\begin{array}{c}29 \\
(24.2)\end{array}$ & $\begin{array}{c}19 \\
(15.8)\end{array}$ & $\begin{array}{c}2 \\
(1.7)\end{array}$ & $\begin{array}{c}120 \\
(100)\end{array}$ \\
\hline 4 & $\begin{array}{l}\text { A quiet } \\
\text { pedestrian } \\
\text { area invites } \\
\text { crime }\end{array}$ & $\begin{array}{c}\text { Total } \\
(\%) \\
\text { Mean }\end{array}$ & $\begin{array}{c}0 \\
(0) \\
3.80\end{array}$ & $\begin{array}{c}15 \\
(12.5)\end{array}$ & $\begin{array}{c}18 \\
(15)\end{array}$ & $\begin{array}{c}64 \\
(53.3)\end{array}$ & $\begin{array}{c}23 \\
(19.2)\end{array}$ & $\begin{array}{c}120 \\
(100)\end{array}$ \\
\hline 5 & $\begin{array}{l}\text { Dark area at } \\
\text { night invites } \\
\text { crime }\end{array}$ & $\begin{array}{c}\text { Total } \\
(\%) \\
\text { Mean }\end{array}$ & $\begin{array}{r}0 \\
(0) \\
3.61 \\
\end{array}$ & $\begin{array}{c}16 \\
(13.3)\end{array}$ & $\begin{array}{c}30 \\
(25)\end{array}$ & $\begin{array}{c}59 \\
(49.2)\end{array}$ & $\begin{array}{c}15 \\
(12.5)\end{array}$ & $\begin{array}{c}120 \\
(100)\end{array}$ \\
\hline
\end{tabular}


Na'asah Nasrudin, Muna Sarimin \& Norhayati Ibrahim

Assessing a Walkable Environment in Jalan Tuanku Abdul Rahman, Kuala Lumpur, Malaysia

Table 3 shows the respondents' perception on the pedestrian walkway safety and security elements at Jalan TAR. They were asked to value five main elements for safety and security i.e. feeling safe when walking along the pedestrian area, feeling safe when crossing the street, reasonable distance between the main road and the sidewalk, quietness of the street invites crime and inadequate night lighting invites crime. The result indicates that quietness and inadequate night lighting along the pedestrian area were their utmost concern on the safety elements. They highly perceived that both circumstances of quietness and inadequate lighting will affect their safety as they will invite crime (mean score of 3.80 and 3.61 respectively).

Meanwhile, majority of the respondents agreed that they generally feel safe and secure when walking at the pedestrian area with a mean score of 3.26. They feel slightly unsafe, however, when crossing the street (mean at 2.76) and walking at the walkway where the distance of the walkway was too near to the main road.

\section{Elements of Enjoyment}

Factors affecting the vibrancy of urban areas vary and are much influenced by such variables as aesthetical values, physical attractions and environmental excitement. This relates to how much of the environment gives aesthetically pleasing to the consumer, attracting traders using the space, and they are happy with the opportunities offered (Owen, Humpel, Leslie, Bauman, \& Sallis, 2004; Shay, Spoon, \& Khattak, 2003).

In Table 4, the majority of the respondents agreed that there is interesting view including heritage and historical building nearby Jalan TAR pedestrian walkway. They also agreed that the existence of art street music such as 'busking' will catch pedestrians' attention resulting in them spending more time at the pedestrian walkway. The respondents also agreed that there is memorable character along Jalan TAR walkway that will attract people to come and spend their time in Jalan TAR. However, respondents averagely agreed that the pedestrian walkway has interesting wall street art and nice landscape along.

Table 4: Pedestrians perception on Jalan TAR enjoyment

\begin{tabular}{|c|c|c|c|c|c|c|c|c|}
\hline & Elements & & $\begin{array}{c}(1) \\
\text { Strongly } \\
\text { Disagree }\end{array}$ & $\begin{array}{c}(2) \\
\text { Disagree }\end{array}$ & $\begin{array}{c}(3) \\
\text { Average }\end{array}$ & $\begin{array}{c}\text { (4) } \\
\text { Agree }\end{array}$ & $\begin{array}{c}(5) \\
\text { Strongly } \\
\text { Agree }\end{array}$ & Total \\
\hline & \multicolumn{8}{|l|}{ Enjoyment } \\
\hline 1 & $\begin{array}{l}\text { Interesting } \\
\text { view such as } \\
\text { heritage } \\
\text { building }\end{array}$ & $\begin{array}{c}\text { Total } \\
(\%) \\
\text { Mean } 3.42\end{array}$ & $\begin{array}{c}4 \\
(3.3)\end{array}$ & $\begin{array}{c}11 \\
(9.2)\end{array}$ & $\begin{array}{c}40 \\
(33.3)\end{array}$ & $\begin{array}{c}61 \\
(50.8)\end{array}$ & $\begin{array}{c}4 \\
(3.3)\end{array}$ & $\begin{array}{c}120 \\
(100)\end{array}$ \\
\hline 2 & $\begin{array}{l}\text { Wall street } \\
\text { art along } \\
\text { pedestrian } \\
\text { walkway }\end{array}$ & $\begin{array}{c}\text { Total } \\
(\%) \\
\text { Mean } 3.20\end{array}$ & $\begin{array}{c}2 \\
(1.7)\end{array}$ & $\begin{array}{c}27 \\
(22.5)\end{array}$ & $\begin{array}{c}47 \\
(39.2)\end{array}$ & $\begin{array}{c}40 \\
(33.3)\end{array}$ & $\begin{array}{c}4 \\
(3.3)\end{array}$ & $\begin{array}{c}120 \\
(100)\end{array}$ \\
\hline
\end{tabular}


PLANNING MALAYSIA

Journal of the Malaysia Institute of Planners (2018)

\begin{tabular}{|c|l|ccccccc|}
\hline 3 & $\begin{array}{l}\text { Art street } \\
\text { music along } \\
\text { pedestrian } \\
\text { walkway }\end{array}$ & $\begin{array}{c}\text { Total } \\
(\%) \\
\text { Mean 3.16 }\end{array}$ & $\begin{array}{c}5 \\
(4.2)\end{array}$ & $\begin{array}{c}20 \\
(16.7)\end{array}$ & $\begin{array}{c}46 \\
(38.3)\end{array}$ & $\begin{array}{c}47 \\
(39.2)\end{array}$ & $\begin{array}{c}2 \\
(1.7)\end{array}$ & $\begin{array}{c}120 \\
(100)\end{array}$ \\
\hline 4 & $\begin{array}{l}\text { Good } \\
\text { landscaping }\end{array}$ & $\begin{array}{c}\text { Total } \\
(\%)\end{array}$ & 3 & 22 & 48 & 42 & 5 & 120 \\
Mean 3.20 & $(2.5)$ & $(18.3)$ & $(40)$ & $(35)$ & $(4.2)$ & $(100)$ \\
\hline 5 & $\begin{array}{c}\text { Total } \\
(\%)\end{array}$ & 6 & 13 & 36 & 47 & 18 & 120 \\
& $\begin{array}{l}\text { Has a } \\
\text { memorable } \\
\text { character }\end{array}$ & $\begin{array}{c}(10.8) \\
\text { Mean 3.49 }\end{array}$ & & $(30)$ & $(39.2)$ & $(15)$ & $(100)$ \\
\hline
\end{tabular}

\section{Respondents' Agreement with the Proposed Walkable Environment Elements}

Table 5 shows the results of the analysis on respondents' level of agree or disagree with the proposed walkable environment enhancement measures. For this analysis, the respondents were given a list of proposed walkable environment enhancement measures and asked to provide an opinion to what extend were they agree or disagree with the suggestions.

The proposal to restrict the vendors and hawkers from using the pedestrian walkway and to provide more shady areas and shelter were the most popular proposals (with mean score of 4.61 and 4.52 respectively). These are then followed by the proposal to improve proper signage and warnings, restrict the streets beggar, provide better landscaping as well as maintain cleanliness along the pedestrian walkway. Meanwhile, providing murals and street arts to enhance the sense of welcoming to encourage people to walk and planting more trees along the pedestrian walkway were given the least priority.

Table 5: Mean Analysis of walkable environment enhancement

\begin{tabular}{|c|l|c|}
\hline No. & \multicolumn{1}{|c|}{ Proposal } & $\begin{array}{c}\text { Mean Score of } \\
\text { agreement }\end{array}$ \\
\hline 1 & $\begin{array}{l}\text { Shade trees along the pedestrian walkway, provide a sense of } \\
\text { enclosure, privacy, and security }\end{array}$ & 3.40 \\
\hline 2 & $\begin{array}{l}\text { Soft and hard landscape to beautify and enhance the overall } \\
\text { environment }\end{array}$ & 3.96 \\
\hline 3 & $\begin{array}{l}\text { Frequent maintenance and proper cleanliness along the pedestrian } \\
\text { walkway }\end{array}$ & 3.74 \\
\hline 4 & $\begin{array}{l}\text { Provide more murals and street art to enhance the sense of } \\
\text { welcoming environment. }\end{array}$ & 4.65 \\
\hline 5 & Proper signage and warnings to create a safer environment & 4.52 \\
\hline 6 & Provide shady trees and shelter where necessary & 4.61 \\
\hline 7 & $\begin{array}{l}\text { Restrict the vendors and hawkers using the pedestrian sidewalk } \\
\text { space }\end{array}$ & 3.98 \\
\hline 8 & Restrict the street beggar using the pedestrian sidewalk space & \\
\hline
\end{tabular}


Na'asah Nasrudin, Muna Sarimin \& Norhayati Ibrahim

Assessing a Walkable Environment in Jalan Tuanku Abdul Rahman, Kuala Lumpur, Malaysia

\section{CONCLUSION}

This study concludes that Jalan TAR pedestrian walkway has comfort and enjoyable elements as it able to offer both emotional and physical harmony between the human body and the environment. However, majority respondents were quite sceptical on safety and security issues and did not give a positive feedback which limits the overall walkability values of the area. This suggests that improvement is needed to further enhance the walkable criteria. As walkability environment should be the asset of a city whereby tourists get attracted to experience the place, there is a need to create a pedestrian walkway that is walkable, distinctive with a strong identity and sense of place. A pedestrian walkway with good and quality design will encourage greater community participation in walking and can influence emotional comforts and experience while walking. Sheltered walkway should be provided where necessary to shield the pedestrians from the hot weather and rainy days, and tree planting is seen a natural solution to these problems. The design and provision of all important walkway elements and street furniture (including public art) should be coordinated, wherever possible, to make a positive contribution, avoid unnecessary clutter, and ensure a safe, informative and attractive walking environment.

\section{ACKNOWLEDGEMENT}

The authors would like to thank the Ministry of Higher Education, Malaysia for funding this research through the FRGS grant (FRGS/1/2016/SS07/UITM/02/5) and Universiti Teknologi MARA (UiTM) for supporting the research.

\section{REFERENCES}

Alfonzo, M. A. (2005). To walk or not to walk? The hierarchy of walking needs. Environment and Behaviour, 37, 808-836.

Bouscasse, H., Joly, I., \& Bonne, P. (2018). How does environmental concern influence mode choice habits? A mediation analysis. Transportation Research Part D: Transport and Environment, 59, 205-222.

Brown, B. B., Werner, C. M., Amburgey, J. M., \& Szalay, C. (2007). Walkable Route perception and Physical Features: Converging Evidence for En Route Walking Experience. Environment and Behaviour, 39, 34-61.

Evans, G. (2009). Accessibility, urban design and the whole journey environment. Built Environment, 35(3), 366-385.

Handy, S., Xinyu, C., \& Mokhtarian, P. L. (2005). Correlation or causality between the built environment and travel behavior: Evidence from Northern California. Transportation Research Part D: Transport and Environment, 10(6), 427-444.

Jacobs, J. (1969). The death and life of great American cities. New York: The Modern Library. 
Llewelyn-Davies (Firm). (2000). Urban design compendium. United Kingdom: English Partnership \& The Housing Copporation, UK.

Lynch, K. (1960). A Imagem Da Cidade (The Image of the City) (1996 $6^{\text {th }}$ ed). Lisboa: Edicoes 70.

Newman, O. (2008). Creating defensible space. Darby, PA: Diane.

Owen, N., Humpel, N., Leslie, E., Bauman, A., \& Sallis, J. F. (2004). Understanding environmental influences on walking. American Journal of Preventive Medicine, 27(1), 67-76.

Parks, J. R., \& Schofer, J. L. (2006). Characterizing neighborhood pedestrian environments with secondary data. Transportation Research Part D: Transport and Environment, 11(4), 250-263.

Rahaman, K. R., Lourenco, J. M., \& Viegas, J. M. (2012). Perceptions of pedestrians and shopkeepers in European medium-sized cities: Study of Guimara-tildees, Portugal. Journal of Urban Planning and Development, 138(1) 26-34.

Sarkar, A. K., \& Janardhan, K. S. V. S. (1997). A study on pedestrian flow characteristics. Proceedings Transportation Research Board, 368, 232-238. Washington: (n.p.).

Shamsuddin S., Hassan N. R. A, \& Bilyamin S. F. I. (2012). Walkable environment in increasing the liveability of a city. Procedia-Social and Behavioral Sciences, 50, 167-178.

Shay, E., Spoon, S. C., \& Khattak, A. J. (2003). Walkable environment and walking activity. Chapel Hill: University of North Carolina.

Slater, K. (1985). Human comfort. Springfield, IL: Charles C. Thomas Publisher.

Southworth, M. (2005). Designing the walkable city. Journal of Urban Planning and Development, 131, 246-257.

Tarudin, N. F., Rashid, M. F. A., Kordi, N. E, Azmi, E. A., \& Aziz, T. N. A. T. (2016). The Improvement on the Sidewalk in Commercial Areas at City Center in Malaysia. Journal of Applied Environmental and Biological Sciences. 6(9S)3538.

Zakaria, J., \& Ujang, N. (2015). Comfort of walking in the city center of Kuala Lumpur. Procedia - Social and Behavioral Sciences, 170, 642-652. 